\title{
Evolution of Chinese Characters and Knowledge Management
}

\author{
Valerie (C.Y.) ZHU ${ }^{1, a,{ }^{*}}$, Jun WANG ${ }^{2, b}$, W.B. LEE $^{3, c}$ \\ ${ }^{1}$ The School of Management of Xi'an University of Science \& Technology, No. 58, Yan'ta Road, \\ 710054 Xi'an China \\ ${ }^{2}$ Xian University of Finance \& Economics, No.2, South of Wei'chang Road, Chang'an District \\ 710100, Xi'an, China \\ ${ }^{3}$ Knwoledge Managemnet Research Center, the Hong Kong Polytechnic University Hung Hom \\ Kowlong, Hong Kong \\ avaleriezhu@mail.xjtu.edu.cn, bw1229@vip.163.com, mfwblee@inet.polyu.edu.hk \\ ${ }^{*}$ Corresponding author
}

Keywords: Oracles, Chinese characters, Evolution, Knowledge management, Heritage.

\begin{abstract}
Language is part of national culture, which ingrains (embeds) values system and life style of the people in which it is applied. Retrospect to human history, we once has the most important and the most ancient civilizations----Egypt, ancient Babylon, India and China. As time went by, the other three ancient civilizations have faded away; only Chinese civilization remained and maintained continuous development. The mystery lies in Chinese characters---the carrier and transmitter of language and human thoughts. As regards Chinese characters, the most important contribution will be conferred upon the oracles---the earliest Chinese characters which have been carved on animal bones and tortoise shells as early as in the Shang Dynasty. Thanks to great powerful life of Chinese characters, Chinese civilization has the opportunity to remain longevity. Though oracles have evolved with time later on, the essence and cream of Chinese characters carrying the footprint of life and mentality of people in China still can be "smelled". Adopting hermeneutic approach and based on large quantities of literature review, interviewing with concerning experts, this paper is attempting to dig out the secrets of how ancient Chinese people have managed knowledge under the real contexts of their life.
\end{abstract}

\section{Introduction}

Going through the whole human history, there is one thing in common all over the world, that is, the appearance of the witch culture. The same is true of Chinese civilization. In the Shang Dynasty in Chinese history, in order to reach consensus in rational and fair way and be free from conflicts, whenever people want to make decisions, they would carve the events that they are intending to do on tortoise shells and animal bones. With the burning of the carvings, cracks turn up on the tortoise shells and animal bones and different cracks have different interpretations which imply what are the right things that people should do. This is the root cause why oracles exist. In ancient times in lots of countries, there once appeared pictographic characters, such as in Egypt, in China and some other South American countries (e.g. Mayan Culture). But all those have disappeared; only Chinese oracles remained. As written language, it has not only worked as powerful ties to link Chinese, but also laid a great influence upon neighboring countries like Japan, Korea, Singapore, etc. Chinese characters assured the cultural similarities with these neighboring countries. Being the language with the largest population who are using it, it worked in the past, is still working today and will still work in the future as the cultural heritage. It has demonstrated its great power to link people together. In this paper, the authors are intending to pierce the veil of Chinese oracles and are attempting to expose the implications and interpretations of Chinese characters in the perspective of knowledge management.

With the appearance of oracles from the Shang Dynasty, it has experienced rounds of evolutions 
along with the ups and downs of the development of Chinese civilization. No matter how the history alters, oracles have been evolving as well with the changing of societies. Since its turning up, oracles have become the earliest written language and pictographs have been seen as the earliest human written language in the world. At the same time in other parts of the world, such as Egyptian civilization and Mayan culture, there once also emerged pictographs as their languages, but all these have disappeared with the emergence of letter-driven languages, which is a completely different language system. Only Chinese written language maintained and developed and lasted for thousands of years. How can it be possible and why is it that? This paper aims at digging out the myths and mysteries of how Chinese language originated from oracles could achieve such longevity. Based on the investigation of this, the implications and interpretations of oracles pertinent to knowledge management have been exposed. Authors of the paper call special attentions from knowledge management researchers and practitioners on how to assure an effective and efficient knowledge management outcome after getting to know how ancient Chinese people manage knowledge from the perspective of the evolution of Chinese characters. Meanwhile, it is expected that Chinese characters as a language which accommodates the largest share of users in the world will have a day when it can also be designed into a computer-based operating system to facilitate the inputting and processing of the language, just like the role that English plays all over the world today.

The research of the creation and evolution of Chinese oracles should be seen from the lenses of the level of philosophy. Given that the latest philosophical ideas have been adopted, people must throw away the paradigm of already accepted mindset--- that is, to observe and understand things in an either "yes" or "no" simple pattern. The realistic and more comprehensive mindset when people look at things should be from the angles of a three dimensional panoramic perspective, which is the paradigm required by the systems logic)

Table 1 The developmental Stages of Paleography in the World

\begin{tabular}{|l|}
\hline Void of Written Language Period: use pictures to express meanings (ideographs) \\
\hline Pre-Written Language Period: written language used to express meanings (ideographs) \\
\hline $\begin{array}{l}\text { Written language Period: Written language not only express meanings but also have } \\
\text { pronunciation }\end{array}$ \\
\hline $\begin{array}{l}\text { Primitive images to record events------pictographs-------sense-making characters } \\
\text {------syllable-based language ------letter-based language }\end{array}$ \\
\hline
\end{tabular}

Any language, either written form or oral form has to follow the widely accepted communication model:

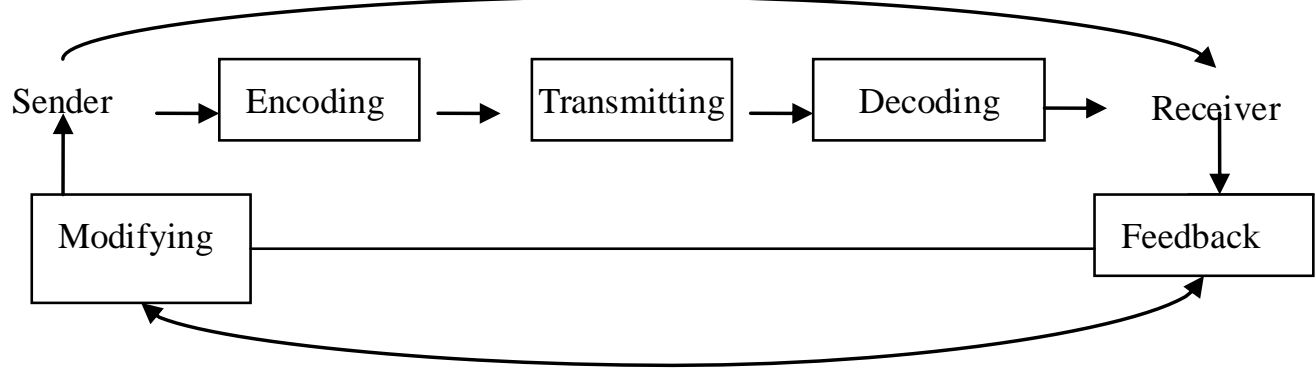

Figure 1 General Communication Model

Communications have been flown along the locus of such closed loop which has made it possible for people to share information, ideas and anything that the senders want to transmit to the receivers. In the meanwhile, after the receivers receive the messages from the senders, they have the opportunity to verify, modify and even refute the message. Then such positive or negative feedback will enable the sender to reconsider the message that he or she has sent out. Such processes can be 
going on and on until the senders and receivers are all satisfied with the messages they have communicated. The evolution of Chinese characters has been going through a similar developmental procedure. At the very beginning, the so-called scholars carved the lines and symbols on the animal bones and tortoise shells to help tribal people reach consensus and make decisions. Communication was first conducted among the people within the same community, and then expanded to other tribes. With the expansion and extension of communication scopes and scales, characters have been propagated and become popular among more and more people. When life has become enriched, information exploded, there were demands for large quantities of Chinese characters, and as a result, characters were not only created through merely carving, but also there appeared large number of associative compounds, self-explanatory characters and picot-phonetic characters, as well as synonymous characters.

To make a long story short, from the appearance of Chinese characters---the oracles down through the development of Chinese characters, it is transparent and revealed that the appearance of oracles have followed the following three principles:

1. The principle of common sense: the emergence of any Chinese characters is the reflection of the experiences and scenarios of the people at the same community. Only based on the common sense and shared life experiences, can the characters be shared and identified by members of the community. Without the shared life experiences and consensus among group members, characters created will not be shared and identified in the given community and communication purposes will not be achieved.

For example: the emergences of 10 earthly branches, (which represent the strategic alliances of ten tribes, also a reflection of the social life and reality of the society at that time) and 12 heavenly stems (which is the depiction and reflection of the process of how woman gives birth to a baby, also a reflection of ancestor's worship for reproduction culture).

\section{Principles for creating of oracles}

From the unearthed oracle pieces, there are about 3500 Chinese characters that can be recognized and understood. Based on the identification and understanding of these oracles, from which three basic principles can be generalized.

To be specific, the principle of common experiences pertinent to living conditions; principle to use pictographs to express meanings; as well as people-orientated principle. These three principles have been ingrained into the whole process in the creation of oracles. The people-oriented (people first principle) principle: when the oracles emerge in people's life, it takes people as the core, as people matter quite a lot in social life. Being absence of high-technological weapons and strongly restrained by limited resources for ancient people to survive, people are really of the utmost importance for the survival of a tribe. Without people, a tribe may be defeated or extinguished by another tribe.

To speak from the stems that play the key role in forming of Chinese character, they can be categorized into characters stems related to human body, which consists of almost every part of human body, such as posture, hand and arm, five senses, other body organs; character stems related to gender and sexual relationship, for instance the 12 Earthly Stems, reproduction organs of male and female, the sexual relations between male and female, as well as the reproduction organs of animals; character stems related to the Earth and the Heaven, for example, the Sun, the Moon, clouds, atmosphere, rainfall, stars, earth, stones, mountains, hills, fire, water, fountains, etc.; character stems derived from animals of all kinds that stayed with the ancestors at that time, for example, ox, sheep, dog, horse, pig, bird, tiger, wolf, elephant, scorpions, turtles, fish, etc., character stems derived from plants of varieties, such as wood, grass, bamboo, wheat, melons, rice, etc.; character stems derived from tools, like 10 Heavenly Branches, weapons, utensils, containers, etc.; character stems derived from real life experiences, such as house, transportation, clothes, food 
utensils, as well as living habits and culture, like sacrificing, cemetery, etc.; the other type of character stems have been originated from abstract mentality but partially pertinent to real life experiences, such as the stems that indicate upward, downward, etc.
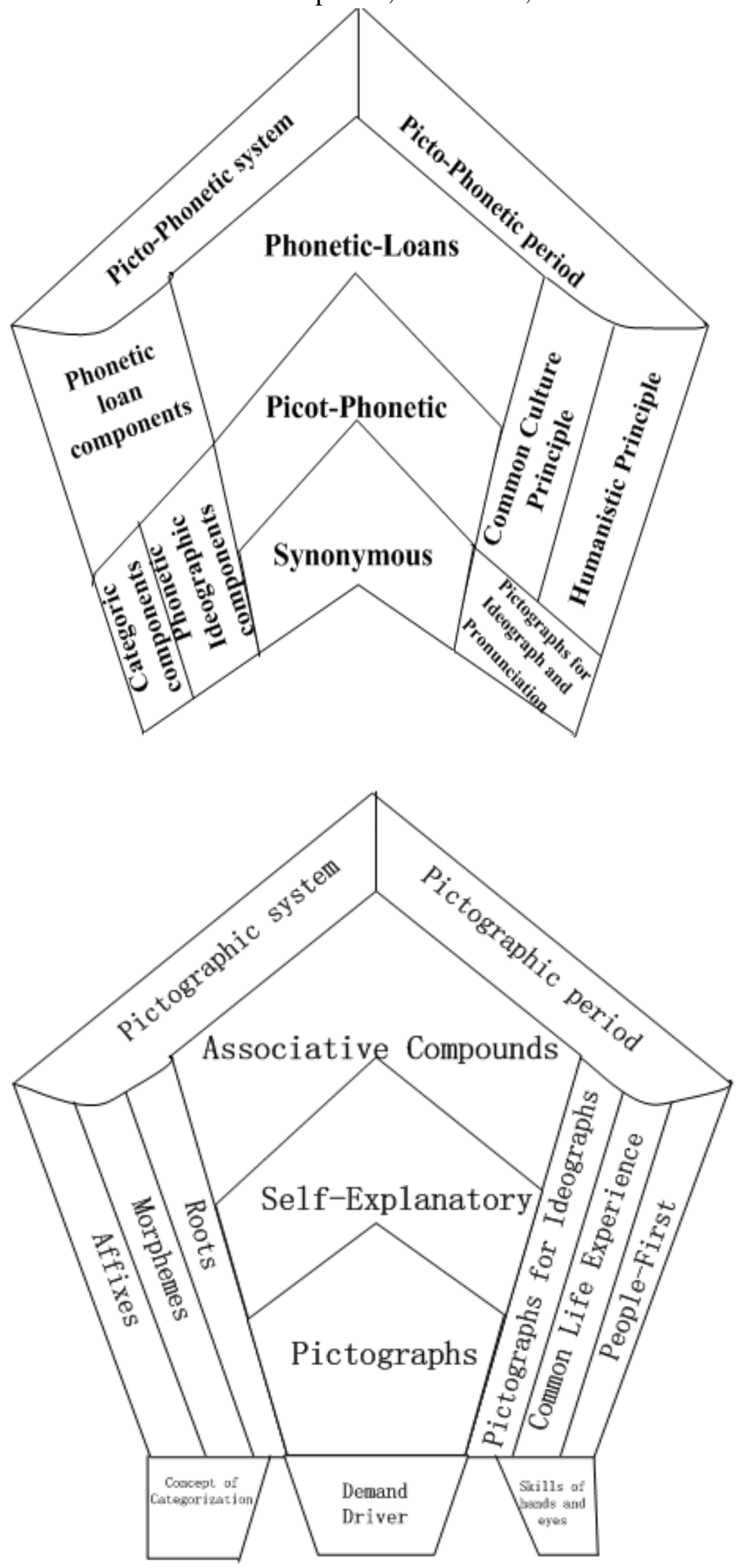

Figure 2 Illustration of the Systematic Structure of Chinese Characters 
The creation of Chinese oracles can be summarized into the six categories of Chinese characters, or rather pictographic characters, self-explanatory characters, associative compounds, mutually explanatory characters, phonetic loan characters, and picot-phonetic characters. Looking through the evolution of Chinese characters, there experienced two systems--- that is, the pictographic system of Chinese characters and the picot-phonetic system of Chinese characters. The general evolutionary system of Chinese characters can be illustrated in figure 2 as shown above:

The creation of 12 Earthly Stems has vividly described the whole process of baby birth. It is the ancestors' wishes for the boom of the population, which is the essential requirement for the prosperity of tribes at that time. Therefore, the creation of 12 Earthly Stems is the reflection of the living conditions of ancient people. It indicates the holy and scared worship of ancestors for reproduction of population. Apart from the expression of birth culture, reproduction culture, gender culture, these 12 Earthly Stems have also been used to indicate 12 time zones, each stands for 2 hours.

The creation of 10 Heavenly Branches are the most important ten tribes in the Shang Dynasty, each specializing in making a certain kinds of tools they need for survival at that dreadful living environment. In order to raise efficiency and integrate limited resources, every two tribes have united as a strategic alliance to enhance their competitive advantages.

12 Earthly Stems and 10 Heavenly Branches played an important role in people's life and such influence has been maintaining and extending even to date. 24 hours a day has been demonstrated by the 12 Earthly Stems, each stem stands for two hours. In addition, the combination of 12 Earthly Stems and 10 Heavenly Branches have been used to represent 60 years as a cycle. Moreover, the 12 animals (rat, ox, tiger, rabbit, dragon, snake, horse, sheep, monkey, chicken, dog, pig), representing 12 Earthly Stems have been used to symbolize the year in which a person is born. Such tradition has been handed down from generation to generation for more than 4,000 years.

\section{Primitive model of knowledge management implied from the creation of oracles}

Looking through the essence and cream of how ancestors have created oracles, it is observable and self-explanatory that the creation of oracles (knowledge creation) is deeply rooted in real life experiences; the fundamental purpose for the creation of oracles is to meet the basic requirement of communication and achieving consensus (why knowledge is necessary? The preliminary purpose for the existence of knowledge---usefulness); the most essential consideration for people to share knowledge is building trust. Oracles, first of all, have been identified and used among members of the same tribes; then flow to the other tribes which have marriage ties with each other, like the tribes which formulated strategic alliances (as explained in the 10 Heavenly Branches); furthermore, the profound abundance of information and enriched life experiences have pushed the development of oracles; the evolution of oracles also follows the rule of "survival of the fittest". Oracles which have been unanimously accepted and in conformity with life experiences have been retained and developed, but those that are far beyond the life experiences and rarely used in life have been eliminated automatically. The flow of characters has also enlarged the communication scope and scale which in turn, helps the development of oracles.

Table 2 The Evolution of Chinese Characters

\begin{tabular}{|c|c|c|c|c|c|}
\hline & $\begin{array}{l}\text { The } 1^{\text {st }} \\
\text { stage }\end{array}$ & \multicolumn{3}{|c|}{ The $2^{\text {nd }}$ stage } & The third stage \\
\hline Time span & $\begin{array}{l}\text { Prior to the } \\
\text { Spring \& } \\
\text { Autumn and } \\
\text { the Warring }\end{array}$ & $\begin{array}{l}\text { From the } \\
\text { Qin, Han } \\
\text { down to } \\
\text { the Tang }\end{array}$ & $\begin{array}{l}\text { Inclusive } \\
\text { of the } \\
\text { Song, } \\
\text { Yuan and }\end{array}$ & $\begin{array}{l}\text { The Qing } \\
\text { Dynasty }\end{array}$ & $\begin{array}{l}\text { Modern times(From May Fourth } \\
\text { Movement) }\end{array}$ \\
\hline
\end{tabular}




\begin{tabular}{|c|c|c|c|c|c|}
\hline & \begin{tabular}{|l} 
States \\
Period
\end{tabular} & Dynasty & $\begin{array}{l}\text { Ming } \\
\text { Dynasties }\end{array}$ & & \\
\hline $\begin{array}{l}\text { Principles to } \\
\text { make } \\
\text { Chinese } \\
\text { characters }\end{array}$ & $\begin{array}{l}1 . \\
\text { Pictographs } \\
\text { imply } \\
\text { meanings } \\
\text { 2. common } \\
\text { life } \\
\text { experiences } \\
\text { 3. } \\
\text { Humanism }\end{array}$ & $\begin{array}{l}1 . \\
\text { pictograp } \\
\text { hs not } \\
\text { only } \\
\text { imply } \\
\text { meanings } \\
\text { but also } \\
\text { stand for } \\
\text { pronunci } \\
\text { ations } \\
2 . \\
\text { common } \\
\text { culture } \\
3 . \\
\text { humanis } \\
\text { m }\end{array}$ & $\begin{array}{l}1 . \\
\text { pictograph } \\
\text { s not only } \\
\text { imply } \\
\text { meanings } \\
\text { but also } \\
\text { stand for } \\
\text { pronunciat } \\
\text { ions } \\
2 . \\
\text { common } \\
\text { culture } \\
3 . \\
\text { humanism }\end{array}$ & $\begin{array}{l}1 . \\
\text { pictographs } \\
\text { not only } \\
\text { imply } \\
\text { meanings } \\
\text { but also } \\
\text { stand for } \\
\text { pronunciati } \\
\text { ons } \\
2 . \text { common } \\
\text { culture } \\
3 . \\
\text { humanism }\end{array}$ & Symbols of Chinese characters \\
\hline $\begin{array}{l}\text { Factors in } \\
\text { creating } \\
\text { character }\end{array}$ & $\begin{array}{l}\text { 1. Stem(less } \\
\text { than 300) } \\
\text { 2.prefix/suff } \\
\text { ix/infix } \\
\text { 3. } \\
\text { morphemes }\end{array}$ & $\begin{array}{l}\text { Radical } \\
\text { compone } \\
\text { nts }(\text { Phon } \\
\text { etics/Ideo } \\
\text { graphs } \\
\text { and } \\
\text { categorie } \\
\text { s) }\end{array}$ & $\begin{array}{l}\text { Radical } \\
\text { componen } \\
\text { ts(Phoneti } \\
\text { cs/Ideogra } \\
\text { phs and } \\
\text { categories) }\end{array}$ & $\begin{array}{l}\text { Radical } \\
\text { components } \\
\text { (Phonetics/I } \\
\text { deographs } \\
\text { and } \\
\text { categories) }\end{array}$ & \\
\hline $\begin{array}{l}\text { Criteria for } \\
\text { creating } \\
\text { characters }\end{array}$ & $\begin{array}{l}1 . \\
\text { pictographs } \\
2 . \\
\text { self-explana } \\
\text { tory } \\
3 . \\
\text { associative } \\
\text { compounds }\end{array}$ & $\begin{array}{l}\text { 1.synony- } \\
\text { mous } \\
\text { characters } \\
\text { 2.picot- } \\
\text { phonetic } \\
\text { character } \\
\text { s } \\
\text { 3.phone- } \\
\text { tic loan } \\
\text { charac- } \\
\text { ters }\end{array}$ & $\begin{array}{l}\text { 1.synony- } \\
\text { mous } \\
\text { characters } \\
\text { 2.picot- } \\
\text { phonetic } \\
\text { characters } \\
\text { 3.phonetic } \\
\text { loan } \\
\text { characters }\end{array}$ & $\begin{array}{l}\text { 1.synonym } \\
\text { ous } \\
\text { characters } \\
\text { 2.picot- } \\
\text { phonetic } \\
\text { characters } \\
\text { 3.phonetic } \\
\text { loan } \\
\text { characters }\end{array}$ & \\
\hline $\begin{array}{l}\text { Principles of } \\
\text { pronuncia- } \\
\text { tion }\end{array}$ & $\begin{array}{l}\text { Onomato- } \\
\text { poeia } \\
\text { normally } \\
\text { imitate } \\
\text { animals and } \\
\text { human } \\
\text { beings) } \\
\text { Accompa- } \\
\text { niment with } \\
\text { behaviors } \\
\text { (as part of } \\
\text { human } \\
\text { behaviors) }\end{array}$ & $\begin{array}{l}\text { Based on } \\
\text { the } \\
\text { previous } \\
\text { pronun- } \\
\text { ciation } \\
\text { system, } \\
\text { there are } \\
\text { some } \\
\text { changes } \\
\text { in } \\
\text { pronun- } \\
\text { ciation, } \\
\text { following }\end{array}$ & $\begin{array}{l}\text { Based on } \\
\text { the } \\
\text { previous } \\
\text { pronuncia- } \\
\text { tion } \\
\text { system, } \\
\text { there are } \\
\text { some } \\
\text { changes in } \\
\text { pronuncia- } \\
\text { tion, } \\
\text { following } \\
\text { the }\end{array}$ & 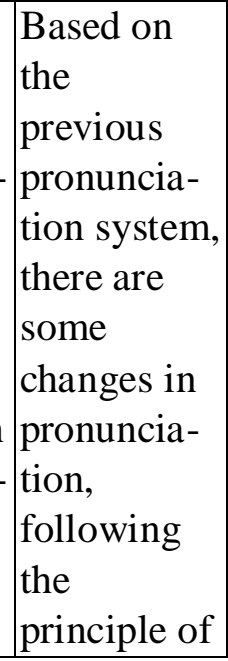 & \\
\hline
\end{tabular}




\begin{tabular}{|c|c|c|c|c|c|}
\hline & $\begin{array}{l}\text { Analogy } \\
\text { originated } \\
\text { from real } \\
\text { life } \\
\text { substances, } \\
\text { like } \\
\text { characters } \\
\text { with the } \\
\text { same } \\
\text { pronuncia- } \\
\text { tion have } \\
\text { the same } \\
\text { implied } \\
\text { meanings. }\end{array}$ & $\begin{array}{l}\text { the } \\
\text { principle } \\
\text { of being } \\
\text { simpli- } \\
\text { fied and } \\
\text { being } \\
\text { easy to } \\
\text { pro- } \\
\text { nounce. } \\
\text { For } \\
\text { example, } \\
\text { previous- } \\
\text { ly people } \\
\text { utter } \\
\text { words } \\
\text { from } \\
\text { their } \\
\text { chest, but } \\
\text { later it } \\
\text { has been } \\
\text { simpli- } \\
\text { fied by } \\
\text { using } \\
\text { their } \\
\text { tongues. }\end{array}$ & $\begin{array}{l}\text { principle } \\
\text { of being } \\
\text { simplified } \\
\text { and being } \\
\text { easy to } \\
\text { pronounce } \\
\text {. For } \\
\text { example, } \\
\text { previously } \\
\text { people } \\
\text { utter } \\
\text { words } \\
\text { from their } \\
\text { chest, but } \\
\text { later it has } \\
\text { been } \\
\text { simplified } \\
\text { by using } \\
\text { their } \\
\text { tongues. }\end{array}$ & \begin{tabular}{|l|} 
being \\
simplified \\
and being \\
easy to \\
pronounce. \\
For \\
example, \\
previously \\
people utter \\
words from \\
their chest, \\
but later it \\
has been \\
simplified \\
by using \\
their \\
tongues. \\
\end{tabular} & \\
\hline $\begin{array}{l}\text { Management } \\
\text { of Chinese } \\
\text { characters }\end{array}$ & & & $\begin{array}{l}\text { Xu } \\
\text { Brothers } \\
\text { compiled } \\
\text { <shuo'we } \\
\text { njie'zi> by } \\
\text { xu shen in } \\
\text { the Han } \\
\text { Dynasty }\end{array}$ & \begin{tabular}{|l|} 
<Kang'xi \\
Grand \\
Dictionary> \\
containing \\
48,000 \\
characters \\
which \\
indicated \\
the collapse \\
of Chinese \\
characters
\end{tabular} & $\begin{array}{l}<\text { Chinese language dictionary and } \\
\text { origin of characters }>\text { by Wang } \\
\text { Yun'wu } \\
<\text { Neo-Chinese Dictionary }>\& \\
<\text { Origin of Chinese Language> }\end{array}$ \\
\hline Principles & & & & & $\begin{array}{l}\text { The unification of Complicated } \\
\text { Chinese characters and the } \\
\text { simplified Chinese characters. } \\
3500 \text { basic characters }(99 \%) ; 7900 \\
\text { secondary Chinese character } \\
(99.9 \%) \text { Writing style and writing } \\
\text { tools also changed from the } \\
\text { vertical into horizontal; and from } \\
\text { writing brush into pens, pensils, } \\
\text { etc. } \\
\text { Tradeoff between the complicated } \\
\text { forms and the simplified forms: } \\
\text { human eyes are attempting to see } \\
\text { characters with bigger }\end{array}$ \\
\hline
\end{tabular}




\begin{tabular}{|l|l|l|l|}
\hline & & & $\begin{array}{l}\text { differentiation, while human hands } \\
\text { attempting simple easy strokes. } \\
\text { Computer has toppled down the } \\
\text { foundation of Chinese characters. }\end{array}$ \\
\hline
\end{tabular}

\section{The evolution of the management of Chinese characters}

Oracles-jin'wen-li'shu-small seal script (As per the standard of Qin and Han Dynasties)-Regular script (Tang Dynasty)

The Creation \& Evolution of the Chinese character management system---from a chronological perspective:

Generally speaking, Chinese characters have developed following the orders of time in such a way:

Oracl $^{1}$-Jin'wen (Zhong' ding' wen) ${ }^{2}-$ shi'gu'wen $^{3}-$ xiao'zhuan $^{4}-1$ l'shu $^{5}-\mathrm{kai}^{\prime}$ 'shu $^{6}-$ cao'shu $^{7}$ xing'shu ${ }^{8}$

As mentioned above, the oracles first appeared in the Shang Dynasty with special personnel carving the events and activities of the tribes on the animal bones and tortoise shells to reach consensus. With the emergence of bronze, such oracles have been carved on the bronze utensils. As for the evolution of Chinese characters, not only the writing forms of the characters have been changed from oracles to seal style, to official style, to cursive style, down to running style, etc. Chinese characters not only worked as the written language for people to communicate, it also developed itself into a kind of art---calligraphy and many outstanding calligraphers emerged in China. Even today, calligraphy is still a very popular art form not only in China, but also in Japan, Korea and some other countries, where overseas Chinese settle down. Besides the writing styles, the materials on which Chinese characters have been "written" have also changed with time. At the very beginning, animal bones and tortoise shells were used as writing materials, later, on bronze utensils, on drum-shaped stone objects, on bamboo slips, on silks and finally on paper.

\section{Chinese characters with the Shang Dynasty}

By the time when oracles appeared as the written language in the Shang Dynasty, it facilitated people in the tribal society to communicate with each other. When bronze emgered, these written symbols have been carved on bronze utensils which has been called "Jin'wen" or "Zhong' ding wen" (meaning inscriptions on bronze objects. "Zhong" in English means Bell and "Ding" in English means bronze utensils, which have been used by ancient people in cooking, sacrificing fighting weapons and wine or food containers, etc.) The unearthed oracle relics came to 100,000 pieces, but only 60,000 pieces remained in China, the remaining pieces were in Japan and Great Britian due to historical reasons.

\section{Chinese characters with the Eastern Zhou Dynasty}

In the eastern Zhou Dynasty, which has been consisting of Spring and autumn and the Warring States Period. The society was ingreat turmoil and chaos, different warlords not only have different

\footnotetext{
1 Oracles: refer to the inscriptions on animal bones or tortoise shells of the Shang Dynasty (16th --- 11th century B.C.)

2 Jin'wen (zhong' ding'wen): refer to the inscriptions on ancient bronze objects (weapons, cooking utensils, etc.)

3 Shi' gu'wen: refer to the inscriptions on drum-shaped stone blocks of the Warring States Period (475---221B.C.)

4 Xiao'zhuan: refer to small-seal styled written Chinese characters adopted as the first unified written language in the Qin Dynasty (221---207B.C.) for standardizing the script.

5 Li'shu: refer to official script of the Han Dynasty (206B.C.---220A.D.) which is simplified from small-seal style.

6 Kai'shu: refer to regular script, another kind of writing style of Chinese characters, which can be divided into dakai and xiaokai, the former refers to regular script in small characters, while the latter in big characters.

7 Cao'shu: refer to Chinese characters executed swiftly and with strokes flowing together in a cursive hand.

8 Xing'shu: Chinese characters writted in a running hand.
} 
languages, but also large quantities of variant characters appeared with different pronunciations. The various dialetcts and written characters have been categorized into four main group: dialect used by the States of Qi, Lu and Yan (grouped as Dong Tu, the eastern part of China); dialect used by the State of Qin (grouped as Xi Tu, the western part of China); dialect used by the States of Han, Zhao and Wei (grouped as Jin Xi, meaning West of ShanXi province today) and dialtect used by the State of Chu (grouped as Chu Xi, meaning the west of Chu, today's Hu'bei, Hu'nan, etc. Actually the soutern part of China today)

\section{Chinese characters with the Qin and Han Dynasties}

During the Warring States Period, there were numerous wars and battles among different states (altogether there were seven states at that time, namely Qi, Chu, Yan, Han, Zhao, Wei and Qin) for many years. In the end, the State of Qin has defeated all other six estates and unified China as the first unified administration which declared the end of the feudal society in China and marked the beginning of the autocratic society. After the unification of the power, Qin Dynasty began to unify Chinese characters and measurement system, as as well the width of the horse carts and roads. The unified Chinese character has been called small seal style and Dialect of the Qin State has been stipulated as the standard pronunciation. Many picot-phonetci characters have been created to enlarge the vocabulary. Nouns and pronouns with plural forms were also emerged, like I (Wo, in Chinese both in singular and plural forms).

Han Dynasty has adopted the language system of the Qin Dynasty. With the enrichment of people's life, the frequency of communication and the expansion of information, the original characters have been extended to a large scale and lots of synonymous characters and picot-phonetic characters appeared to meet the demand of communication. In the early years of the Eatern Han Dynasty, Xu'shen, the first most important paleographer compiled a dictionary inclusive of about 9353 Chinese characters of his time. This great works has been called "Shuo'wen'jie'zi”, meaning implication and interpretation of Chinese characters, which standardized the forms and ideographs of Chinese characters and laid a profound influence on palaeographers in the succeeding dynasties, even today.

\section{Chinese characters with the Sui and Tang Dynasties}

The Sui Dynasty is a transitional period in Chinese history and the most important event for the development of Chinese characters is the appearance of Imperial Examination System (in Chinese called Ke'ju'zhidu). This Imperial Examination System is the first fair and talent promotion system in the world. Those who want to become government officials at all levels must participate in this exam and those who have got the excellent performance will be granted the opportunity to become government officials. Such examination has strict requirement for the examinees to answer the exam questions not only in content, but also in the writing style of Chinese characters. Therefore, through this system, the standardization of Chinese characters has been guaranteed.

The Tang Dynasty has followed the suit of its predecessor-the Sui Dynasty. With the introduction of Buddhism and Indian language, for the first time, Chinese language has got its own pronunciation system (the pin'yin system) and Sun Mian, another paleographer has marked the pronunciation of Chinese characters in Shuo'wen'jie'zi, written by Xu Shen as mentioned before. A book called <Gan'lu'quan'shu> (meaning the imperial requirement for examinees to participate in the Imperial Examination) has been complied and many tablets have been set up nationwide to propagate and standardize Chinese characters in stipulating the styles of writing and meaning. Variant characters and odd characters out of popular usage have been eliminated. Regular style and running style appeared as the mainstream writing style. This is also a period that Chinese characters have been thoroughly arranged, compiled and standardized in writing form, pronunciation and ideograpahy. Anecdotally, Wu Ze'tain, one of the government leaders and the only empress in Chinese history has created 19 chinese characters, but only one remained, which only appeared in 
her name "Wu Zhao". All other 18 characters have been wiped out as those odd characters have opposed the principles of creating Chinese characters----i.e., the principle of common life experiences and humanism. Zhao, this character has reflected the intention of the empress, indicating that woman can also rule the country, govern the nation, as in Chinese culture, man has been symbolized as "Sun" and woman, the "moon".

\section{Chinese characters with the Southern and Northern Dynasties, all through the Ming Dynasty}

Down after the Tang Dynasty till the Ming Dynasty, each period only made compilation and collection of Chinese characters, but not has great contributions to the development of Chinese characters. Such as, <san'ti'xiao'jing> was an outcome of the Northern Wei Dynasty with small seal writing style. Once they also set up tablets nationwide and intended to standardize Chinese characters in wei style, but they did not achieve much success.

\section{Chinese characters with the Qing Dynasties}

In the Qing Dynasty, the Emperor Kang'xi himself arranged a group of talents to compile a huge dictionary called <Kang'xi Grand Dictionary>, which contains 48,000 Chinese characters with very complicated systems in writing and pronunciation and hindered the communication. The appearance of <Kang'xi Grand Dictionary> has marked the total collapse of Chinese character system.

\section{Chinese characters with the Modern Period, initiated by the May Fourth Movement}

With the down of the Qing Dynasty and the emergence of May Fourth Movement, western culture and western ideology poured into China and many scholars announced the complete elimination of Chinese characters. The most typical indicator is that Chinese characters have been simplified in writing and China began its downright westernization. That is why some scholars called May Fourth Movement the "Chinese Character Movement". Though a Movement, the system of Chinese characters has not been systematically altered. After the May Fourth Movement, Chinese characters entered a period of symbol character period, during which there has not been formed an organic system, which calls for the development of interface symbolized system based on internet.

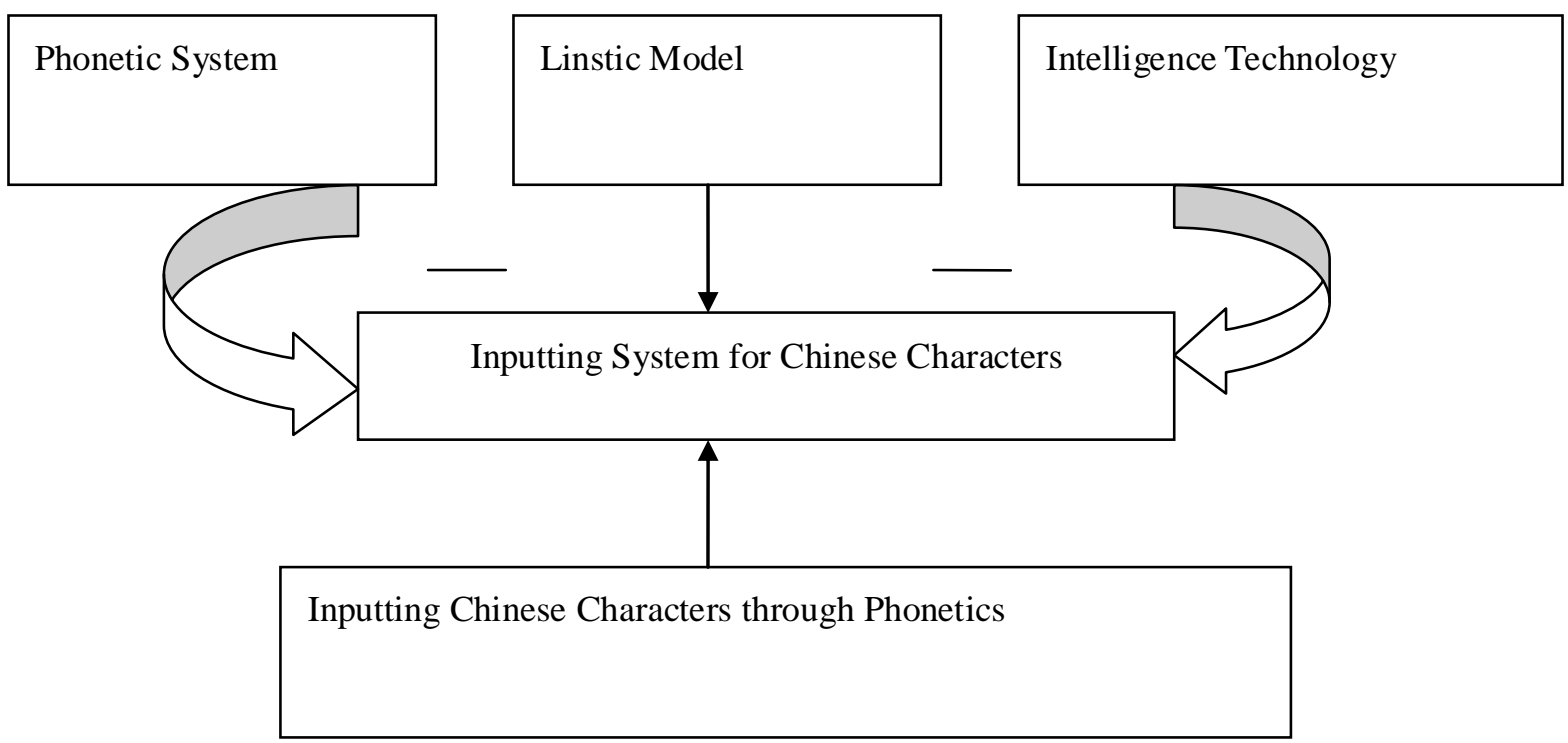

Figure 3 the Future of Chinese Characters in Computer-Based Epoch

Today, Chinese characters are still under reformation and many scholars have expressed their hope to optimize the Chinese character system. That is, there should have two parallel separate systems for writing and reading: the former requires brevity and simplification, while the latter calls for complication and greater differentiation. But with the appearance and widespread adoption of 
computer based operating system, such paradox can be solved. Even at the recent plenary session of the People's Congress, some people have advocated that Chinese characters should return to the complicated forms instead of the simplified characters, but due to various kinds of reasons, this proposal will only become a wishful thinking. Therefore, the fate of Chinese characters will still maintain its separated "fate", i.e. the simplified forms in mainland China and the complicated forms in overseas Chinese. It is proposed and highly expected that new models and technologies have to be designed and developed to solve the problem of "inputting" Chinese characters into computers. The accomplishment and consummation of this proposal will be based on phonetic system + linguistic model + intelligent computer technology; meanwhile phonetic-based inputting system will have to be improved to solve the problem.

\section{Conclusions and Implications in knowledge management}

As early as some 5,000 years ago, ancient Chinese people began to create language which is called oracles. The initial purpose for them to create oracles is only for the facilitation of communication and make decisions when there are no consensus. They may never have expected that their creation can lay a great influence upon their descendents today in knowledge era. Their unconscious and conscious actions have become an invaluable heritage for people today. The systematic arrangement of creation, collection, compilation, storage and development of knowledge has led profound thoughts on us. Additionally, government support and involvement in the whole process of knowledge management is another must for assuring the success of Chinese characters. There are still a lot that have to be done to dig out from the treasure of Chinese characters. This paper only works as a pioneer and vanguard to arouse people's attention and interest in doing further research into the essence and creams of Chinese culture. Let the culture heritage shine as brightly as it can to guide the way forward for us contemporaries.

\section{Acknowledgement}

This research has been sponsored by the foundation of China National Natural Science Foundation (No. U1261111) and Shaanxi Provincial Bureau of Education National Science Foundation (No. 2013JK1193).

\section{Reference}

[1] Byrne, R.M.J. \& Johnson-Laird, P.N. If and the problems of conditional reasoning. Trends in Cognitive Sciences. 13 (2009)282-287.

[2] O’Brien, D. Human reasoning requires a mental logic. Behav. Brain Sci. 32(2009), 96-97.

[3] Mason, D. and Pauleen, D. J. Perceptions of Knowledge Management: A Qualitative Analysis. Journal of Knowledge Management. 7 (2009), pp. 38-48.

[4] Armbrecht, F.M.R., Richard, B.C.J., Chappelow, C.C., Farris, G.F., et al., "Knowledge management in research and development", "Research Technology Management", 44(2001), pp.28-48.

[5] Cheng, P.C. and Holyoak, K.J. Pragmatic reasoning schemas. In Reasoning: studies of human inference and its foundations (Adler, J.E. and Rips, L.J., eds). Cambridge University Press, 2008, pp. 827-842.

[6] Gloet, M. and Berrel, M. “The Dual Paradigm Nature of Knowledge Management: Implications

for Achieving Quality Outcomes in Human Resource Management”, Journal of Knowledge Management, 4(2003)78-89. 
[7] Schroyens, W. et al.. In search of counterexamples: Deductive rationality in human reasoning. Quart. J. Exp. Psychol. 56(2003) 1129-1145.

[8] Tuomi IIkka. Data is more than knowledge: implications of reserved knowledge hierarchy for knowledge management and organizational theory. Journal of Management Information Systems, 1999, 16(3):103-117.

[9] Bertels, Thomas, "King without a castle: How local managers can manage change in a pan-European environment," National Productivity Review, 19(1999)29.

[10]Byrne, R.M.J. The Rational Imagination: How People Create Counterfactual Alternatives to Reality. Cambridge MA: MIT Press, 2005.

[11]Mildeova, S., Vojtko V. (in Czech). Systémová dynamika. Prague: Oeconomica. 2003, pp. 19-24.

[12]Information on http://web.mit.edu/jsterman/www/ford_sterman_elicit_1.pdf.

[13]Barrouillet, P. et al.. Conditional reasoning by mental models: chronometric and developmental evidence. Cognit. 75(2000)237-266.

[14]Cosmides, L. et al. Detecting cheaters. Trends in Cognitive Sciences. 9 (2005), 505-506.

[15]Oberauer K. Reasoning with conditionals: A test of formal models of four theories. Cognit. Psychol. 53 (2006)238-283.

[16]Oaksford, M. and Chater, N. Bayesian Rationality. Oxford University Press, 2007.

[17]Johnson-Laird, P.N.. Mental Models: Towards a Cognitive Science of Language, Inference, and Consciousness. Cambridge: Cambridge University Press, 1983.

[18]Johnson-Laird, P.N. How We Reason. Oxford University Press, 2006.

[19]Johnson-Laird, P.N. and Byrne, R.M.J. Conditionals: a theory of meaning, inference, and pragmatics. Psychol. Rev. 109(2002) 646-678

[20]Verschueren, N. et al.. Everyday conditional reasoning: A working memory-dependent tradeoff between counterexample and likelihood use. Mem. Cognit. 33(2005), 107-119.

[21]Gentner, Dedre and Stevens, Albert L. Ed. Mental Models. Hillsdale NJ: Lawrence Erlbaum Associates, 1983.

[22]Johnson-Laird, P.N.. Mental Models - Towards a Cognitive Science of Language, Inference and Consciousness. Cambridge MA: Harvard University Press., 1983.

[23]Markham, Arthur B.. Knowledge Representation. Mahwah NJ: Lawrence Erlbaum Associates, 1999.

[24]Medin, Douglas and Ross, Douglas. Cognitive Psychology, Second Edition. Fort Worth TX: Harcourt Brace \& Co, 1996.

[25]Rogers, Yvonne, Rutherford, Andrew, and Bibby, Peter (Ed.). Models In the Mind - Theory, Perspective, and Application. London: Academic Press, 1992.

[26]Bollinger, A. S and Smith, R.D. Managing Organizational Knowledge as a Strategic Asset., Journal of Knowledge Management, 5(2001) 8-18

[27]Argote L \& Ingram, P. Knowledge transfer: A basis for competitive advantage in firms Organizational Behaviour and Human Decision Processes, 82(2001), 150-169

[28]Celep. C. and Cetin, B.. Teachers' Perception about the Behaviours of School Leaders with regard to Knowledge Management. The International Journal of Education Management. 19 (2005) 
102-117.

[29]Chin, K. F.. Developing a Knowledge Management Strategy. Price water house Coopers, 2001.

[30]Davenport T. H. Ten principles of Knowledge management and four case studies, knowledge and process management, 14( 1997) 187-208.

[31]Davenport, T.H and Prusak, L.. Working Knowledge: How Organizations Manage What They Know. Harvard Business School Press. Boston. 1998.

[32]De Long, D. W. and Fahey, L.. Diagnosing Cultural Barriers to Knowledge Management. The Academy of Management Executive. 14(2000) 113-127.

[33]Holland, D.. Ten Ways to Embed KM into Organizational Culture. Knowledge Management Review. Issue, March/April, 1999.

[34]Marr, B.. Consider the Culture when Benchmarking KM Processes. KM Review. 5 (2003).6-7.

[35]McDermott, R and O’Dell, C. Overcoming Cultural Barriers to Sharing Knowledge, Journal of Knowledge Management. 5(2001) 76-85.

[36]Nonaka, I, Toyama, R and Konno, N. SECI, Ba and Leadership: a Unified Model of Dynami Knowledge Creation, 2002.

[37]Nonaka, Ikujiro \& Noboru Konno.The concept of "Ba": Building a foundation for knowledge creation. California Management Review; Spring 1998, 40 (3): 40-54

[38]Polanyi, M. Personal knowledge: toward to post-critical philosophy, 1st ed. Chicago: University of Chicago Press. 1958, pp.22-101

[39]Polanyi, M. The tacit dimension. London: Routledge and Kegan Paul. 1966

[40]Robbins, R.F.. Harnessing Group Memory to Build a Knowledge-Sharing Culture. Of Counsel. 22(2003)7-11.

[41]Szulanski, G. Exploring internal stickiness: impediments to the transfer of best practice with the firm. Strategic Management Journal, 1996, 17.

[42]Szutanski, G. The process of knowledge transfer: A diachronic analysis of stickiness. Organizational Behavior and Human Decision Processes, 2000, 82(1) 9-27

[43]Buren M.E.V., A Yardstick for Knowledge Management, Training \& Development, 53(1999) 71-78.

[44]Davenport, Thomas H. \& Long, David W De \& Beers, Michael C., Successful knowledge management projects, Sloan Management Review, 39(1998)43-57.

[45]Edvinsson, Leif, Developing intellectual capital at Skandia, Long Range Planning, 30(1997) 366.

[46]Georg von Krogh., Care in knowledge creation, California Management Review, 40(1998) pp. 133-153.

[47]Nonaka, I, Reinmoeller P., Senoo A., The 'ART' of Knowledge: System to Capitalize on Market Knowledge, European Management Journal, 16(1998)673-684.

[48]Nonaka, I., A dynamic Theory of Qrganizational Knowledge Creation, Organization Science, 5(1994) 14-37.

[49]Nonaka, I., and Takeuchi, H., A theory of organizational knowledge creation, International Journal of Technology Management, 11(1996)833-845.

[50]Thomas A Stewart, Grab a pencil--it's a knowledge quiz, Fortune. New York, 11(1997)241-242. 
[51]Information on http://www.lauradove.info.

[52] Šusta, Marek. "Několik slov o systémové dynamice a systémovém myšlení" (in Czech) (PDF). Proverbs, a.s.. pp. 3-9

[53] Information on http://proverbs.cz/media/art/SM_ST.pdf.

[54]Mildeova, S., Vojtko V. (in Czech). Systémová dynamika. Prague: Oeconomica.2003, pp. 19-24.

[55]Ford, David N., Sterman, John D. Expert Knowledge Elicitation to Improve Mental and Formal Models". Cambridge, Massachusetts, USA - Massachu setts Institute of Technology. pp. 18-23.

[56]Information on http://web.mit.edu/jsterman/www/ford_sterman_elicit_1.pdf. 